\title{
Peace prize rewards physicist of conscience
}

London. Exactly 50 years after the atomic bomb was dropped on Nagasaki and Hiroshima, the Nobel Peace Prize for 1995 has been awarded to the first physicist to have resigned from the war-time Manhattan project in protest at the planned use of the bomb on Japan.

Joseph Rotblat, the Polish-born British physicist, says that he hopes the decision to award the prize jointly to himself and the Pugwash Conferences on Science and World Affairs, in which he has been active for the past 40 years, "will encourage scientists to think seriously about the social implications of their work, and devote a little of their time to address the dangers of science for society".

Having been for several decades at the forefront of international efforts to halt the arms race between the world's superpowers, Rotblat argues that, despite the ending of the Cold War, Pugwash's role remains as important as ever, pointing out, for example, the danger that nuclear weapons will be developed by "rogue nations".

Much of the almost US\$1 million in prize money - which will rescue Pugwash from a permanent state of semi-insolvency, due largely to its refusal to accept funding from governments - will therefore be devoted to its priority of a global treaty banning all nuclear weapons (and not merely their testing or stockpiling).

But the award, although widely welcomed, has been accompanied by its own controversy. This was stirred up by statements from members of the Nobel committee that the decision to honour the activity of a group dedicated to nuclear disarmament was an implicit criticism of France's nuclear tests in the South Pacific. No mention of the French activities was made in the formal citation. But Francis Sejersted, the chairman of the Nobel committee told a press conference in Sweden that the prize was a "specific message" to France.

Such statements have generated a fierce backlash in France, with several newspapers claiming that Pugwash - which, as Rotblat admits, has always maintained a low profile in its activities - might not have been awarded the prize without the intervention of President Chirac. This interpretation is

\section{Tighter ozone targets}

London. The European Union has agreed to press for stricter controls on ozonedepleting substances when international talks on the Montreal Protocol take place in December.

Environment ministers decided to aim for the elimination of methyl bromide, used mainly as a soil fumigant, with a 50 per cent production cut by 2005 , and the elimination of hydrochlorofluorocarbons by 2015. fiercely challenged by those who point to historical precedents, such as the award in 1985 to the International Physicians for the Prevention of Nuclear War, and the fact that, given its contribution to many recent arms limitation agreements, Pugwash had

\section{IMAGE UNAVAILABLE FOR COPYRIGHT REASONS}

Path to peace: Rotblat (left) announces the outcome of first Pugwash conference in 1957, flanked by Cyrus Eaton (right).

apparently been hoping for several years for recognition of its efforts by the Nobel committee.

Rotblat is himself critical of the French activities, which he said had put the nuclear issue back on the international agenda. But he also admits to unease that Pugwash, which tends to avoid open criticism of any government because of its wish to maintain informal contacts, has been inadvertently caught up in the dispute. "I am sorry that the French tests have been brought in in this way," he says.

Rotblat's personal involvement with nuclear weapons took place during his work on the Manhattan Project at Los Alamos in the early 1940s, having been seconded from his position on the physics staff of Liverpool University (he left Poland in 1939 at the outbreak of the war).

He resigned from the project on hearing the news that Germany had dropped its efforts to develop a nuclear weapon - but that the project was to continue, with the new goal of dropping a bomb on Japan. "I joined the project because I knew that the Germans were doing the same thing; once they had stopped, I did not feel it right to continue," he says.

From that time on, Rotblat, while continuing to pursue an academic career - he was professor of physics at St Bartholomew's Hospital Medical College from 1950 to 1976 - devoted much of his energy to eliminating the weapons that the Manhattan project had created.

These efforts led directly to the creation of the Pugwash movement, named after the small town in Nova Scotia where the first meeting, financed by the industrialist Cyrus
Eaton, was held in 1957. Rotblat remained closely identified with the movement, acting as its secretary-general between 1957 and 1973, and chairman of British Pugwash from 1978 to 1988 . Although now aged 86, he remains active in Pugwash affairs.

Unlike many better known organizations, Pugwash has preferred to operate behind the scenes rather than in public. The proceedings of meetings, to which government officials, academics and other scientific and policy experts from around the world are invited in a personal capacity, are held in private, with only a summary report issued at the end.

According to Rotblat and others, this strategy has paid off in laying the groundwork for a number of important international arms control agreements by dealing with the technical issues about how they are likely to be made to work. "The focus has been on the proposition that you have to get the science right, as well as pay attention to the interaction between the scientific and political aspects of problems," says John Holdren, professor of physics at the University of California at Berkeley, and chairman of Pugwash's executive committee.

The strategy of emphasizing the scientific dimension of problems has had the equally important spin-off of providing a channel of communication through which governments in conflict have been able to maintain a dialogue at times - such as the height of the Cold War - when more official channels have been blocked. Indeed, Rotblat claims that acting in this way has been Pugwash's greatest single achievement.

At the same time, this low public profile has made it difficult to spread the organization's more general message about the need for scientists to take responsibility for addressing the negative impacts of science on society, in particular to younger scientists. "There are different niches for different kinds of organization;" Holdren says. "There have been some very effective mass membership organizations, but that is not the way that Pugwash tends to operate."

Furthermore, the thaw in East-West relations has removed much of the need for the type of back-room diplomacy which was Pugwash's forte. "It could certainly be argued that the influence of Pugwash has dropped off a bit," says one regular participant in its conferences.

But Rotblat and others insist that the continued threat of nuclear weapons - as well as more recent threats, such as the possibility for new generations of biological weapons based on the techniques of genetic engineering - mean that the need for Pugwash remains. "It is a different role than during the Cold War; but I do not think it is any less of a role," says Holdren .

David Dickson 